\title{
Recurrent Uterine Smooth-Muscle Tumors of Uncertain Malignant Potential (STUMP): State of The Art
}

\author{
ALESSANDRO RIZZO ${ }^{1}$, ANGELA DALIA RICCI ${ }^{1}$, MARISTELLA SAPONARA $^{1}$, \\ ANTONIO DE LEO $^{2}$, ANNA MYRIAM PERRONE ${ }^{3}$, PIERANDREA DE IACO ${ }^{3}$, \\ MARIA ABBONDANZA PANTALEO ${ }^{1,4}$ and MARGHERITA NANNINI ${ }^{1}$ \\ ${ }^{1}$ Department of Experimental, Diagnostic and Specialty Medicine, \\ S. Orsola-Malpighi University Hospital, Bologna, Italy; \\ ${ }^{2}$ Pathology Unit, S. Orsola-Malpighi Hospital, Bologna, Italy; \\ ${ }^{3}$ Gynecologic Oncology Unit, S. Orsola-Malpighi University Hospital, Bologna, Italy; \\ ${ }^{4}$ Giorgio Prodi Cancer Research Center, University of Bologna, Bologna, Italy
}

\begin{abstract}
The term 'uterine STUMP' (smooth-muscle tumors of uncertain malignant potential) is currently used to define a heterogeneous group of uterine tumors distinct from leiomyomas and leiomyosarcomas. This rare entity is often characterized by a slow growth and protracted patient survival when compared to leiomyosarcomas but few data are available about its clinical management and outcome. In this review, we summarize the current state of knowledge about uterine STUMP, with a particular focus on cases of recurrence.
\end{abstract}

The term 'STUMP' i.e. smooth-muscle tumors of uncertain malignant potential, firstly appeared in 1973 to define a category of clinically malignant smooth-muscle tumors not yet distinct from sarcomas (1). In 1994, Stanford investigators published the first data collection about 213 cases of uterine smooth-muscle tumors characterized by low or uncertain malignant potential (2). According to the latest World Health Organization (WHO) definition, uterine STUMPs are smooth-muscle tumors with features that preclude an unequivocal diagnosis of leiomyosarcoma (LMS) although STUMPs do not fulfil the criteria for

This article is freely accessible online.

Correspondence to: Alessandro Rizzo, Medical Doctor, Department of Specialized, Experimental and Diagnostic Medicine, Sant'OrsolaMalpighi Hospital, University of Bologna, Via Massarenti 9, 40138 Bologna, Italy. Tel: +39 0512144078, Fax: +39 0516364037, e-mail: rizzo.alessandro179@gmail.com

Key Words: Smooth-muscle tumors of uncertain malignant potential, recurrence, uterine malignancies, uterine smooth-muscle neoplasms, STUMP, review. leiomyoma (LM), or its variants, and raise concern that the neoplasm may behave in a malignant fashion (3).

In a recent study by Gupta et al., based on the WHO guidelines and experience of four tertiary referral centers, the authors proposed a redefinition of criteria for the diagnosis of uterine STUMP (4). These criteria include the presence of the following features: (a) Tumor necrosis but difficult to define; (b) diffuse or multifocal atypia and mitotic counts near the threshold for malignancy [for example, nine mitoses per 10 high-power fields (HPFs)]; (c) more than 15 mitoses per 10 HPFs; (d) definite coagulative tumor cell necrosis in multifocal or irregularly shaped foci in banal-appearing tumor; (e) atypia or proliferative activity intermediate between their benign and malignant counterparts; (f) myometrial invasion without usual features of malignancy; and (g) atypical mitotic figures without other canonical features of malignancy.

The diversity of definitions of 'STUMP' has led to the fitting expression of 'borderline tumor' in which pathological and clinical parameters of both LM and LMS overlap $(5,6)$. Clinical features and age at diagnosis resemble those of LMS and LM (7). Uterine STUMPs are generally characterized by indolent behavior and protracted survival (8), but several authors report cases of patients with distant metastases and a rapid clinical course $(9,10)$. Radical surgical resection is currently considered the only potentially curative therapy (8). Hysterectomy is recommended as the treatment of choice for women who have no desire for childbearing, while myomectomy is often performed in premenopausal women who desire to maintain fertility $(8,10,11)$. The recurrence rate is about $8.7-11 \%$, and different approaches are reported for the treatment of relapse.

Given the high degree of heterogeneity, no standard guidelines have been defined for diagnosis, treatment and 
follow-up of the disease, and the management of uterine STUMP continues to be considered a challenge. In this review, we summarize the current state of knowledge about STUMP. In our literature search, we found 46 cases of recurrent uterine STUMP, including histopathological, clinical and treatment characteristics.

\section{Review Methods}

We reviewed histopathological features, type of initial surgery, recurrence, treatment of recurrence and clinical outcomes of uterine STUMPs by searching English-language review articles, case reports, case series and book chapters published until May 2019. The electronic search included two databases, PubMed and Google Scholar, and used nine search terms: Uterine smooth-muscle tumor of uncertain malignant potential, STUMP, uterine smooth-muscle tumor, uterine LM, immunohistochemistry, recurrent, relapse, myomectomy and hysterectomy. From the articles retrieved in the first round of the search, additional references were identified by a manual search among the references cited. We selected articles on the basis of quality, relevance to disease, clarity in explaining manner and timing of recurrence, and the level of attention the articles had previously received in the field.

\section{STUMP Versus LM: A Challenging Differential Diagnosis}

From a histological standpoint, the diagnosis of uterine STUMP is usually confirmed by the presence of any unusual combinations of the three features that do not satisfy the current Stanford criteria for LMS such as moderate-to-severe atypia, a mitotic count of $\geq 10$ mitotic figures per $10 \mathrm{HPFs}$, and tumor cell necrosis (12), while the diagnosis of atypical LM is defined by multifocal moderate-to-severe atypia, a mitotic count lower than one mitotic figure per $10 \mathrm{HPFs}$ (according to Stanford criteria) and no tumor cell necrosis (5). Ip et al. stress the importance of the mitotic count in the differential diagnosis between STUMP and LM, in particular for LM with bizarre nuclei (5), although the cut-off threshold is not defined and it is difficult to distinguish degenerating nuclei, the so-called 'pseudo-atypical mitosis' from true mitotic figures (13). Moreover, the hormonal milieu has been hypothesized to modify mitotic count, either endogenously or exogenously $(14,15)$.

Another exception is represented by mitotically active LM, which is regarded as an LM variant with little or no recurrent/metastatic potential that typically arises in the secretory phase of the menstrual cycle and has an increased mitotic activity, especially when there are 10-15 mitotic figures per $10 \mathrm{HPFs}(13,14)$. Some authors report cases of distant metastasis even in patients who underwent hysterectomy for usual-type LM, regarded as benign metastasizing leiomyoma (BML) (16). This uncommon behavior does not allow a definite differential diagnosis based on histopathological features and complicates the therapeutic algorithm between benign-appearing LMs and STUMPs. Barnaś et al. conducted a systematic review that reported a mean time of 8.8 years from primary surgery to BML diagnosis and lungs appear to be the most frequent site of metastasis (17). In an earlier study, Patton et al. demonstrated the role of a high level of estrogen receptors (ER) and progesterone receptors (PR) in development of BML, suggesting the use of ER modulators such tamoxifen in cases of incomplete surgical resection (18). Currently, more than 160 cases of BML have been reported in literature and the number of reported cases of BML after 2010 has outnumbered the sum of all cases published before then $(17,19)$.

According to Amant et al., the presence of coagulative tumor cell necrosis can predict the potential malignancy in uterine smooth cell neoplasms (20). Despite the presence of different types of necrosis, only coagulative has been reported to be typical of LMS and sometimes of STUMP; it is characterized by an abrupt transition from necrotic to nonnecrotic areas, without interposed granulation or fibrocollagenous tissue or associated inflammation $(13,21)$. Tumor necrosis does not necessarily correlate with the malignant clinical course, but it may represent a useful alert to start appropriate follow-up $(20,21)$.

In our literature search, histological features at the time of diagnosis, such as atypia and tumor cell necrosis, were available in 43 and 41 patients, respectively. A moderate, moderate-to-severe and severe degree of atypia was found to be present in 33 patients $(33 / 43,76 \%)$. In 12 out of 41 women, the histological examination revealed the presence of tumor cell necrosis (Table I).

\section{Immunohistochemical Patterns}

Immunohistochemical markers have been used to help pathologists in differential diagnosis, with an immunohistochemical profile of STUMP generally defined as being much closer to LM than LMS (22). Although based on a small number of patients, the study by Mittal and Demopoulos evaluated different immunohistochemical markers to distinguish among LM, STUMP and LMS. More specifically, as regards ER and PR, PR expression was detected in all 8 STUMPs and 14 out of 15 cellular LMs but only in 2 out of 12 cases of LMS. Another aspect that the authors emphasized is occasional positive staining for ER and rare positivity for PR reported in some cases of uterine LMS (22).

Several studies, including that by Mittal et al., also examined p53 expression in uterine smooth-muscle tumors, with no consensus about its relevance in the subcategory of 
STUMPs. Authors agree with the evidence of increasing MIB-1 and p53 expression in LMS concurrently with progressive loss of steroid receptors $(9,22,23)$.

In another study, O'Neill et al. compared p16 expression with MIB1 and p53 expression in 63 patients with smoothmuscle tumors, including four cases of STUMP. Although p16 is an onco-suppressor protein causing $G_{1}$ arrest, its expression seems to be significantly higher in uterine LMS and has been suggested to have an adverse prognostic value in STUMP (9). The same was found by Atkins et al., which underlined that metastasizing STUMP seemed to present strong p16 positivity (24).

In recent years, several studies about immunohistochemistry in uterine smooth-muscle tumors have reported cases of PR positivity in LMS. In detail, PR has been found to be positive in $13.3 \%$ to $60 \%$ of cases $(25-27)$. These studies help to evaluate and define the potential prognostic and therapeutic value of PR expression in LMS. In fact, PR status was subject of a recent study that showed a prognostic value in stage I LMS (28); in this study ER and PR-positive LMS showed better progression-free survival (PFS), opening up the possibility of using adjuvant hormonal therapy $(28,29)$.

These findings were recently confirmed by Zhang et al. (30). In their study, 119 cases of uterine smooth-muscle tumors were reviewed, including LMS, LM and STUMP. PR-positive staining was present in only $10.8 \%$ of LMS cases; on the contrary, diffuse immunoreactivity for PR was present in $88 \%$ of STUMP and $83 \%$ of LM. On the basis of these findings, Zhang et al. support the assessment of PR status to obtain additional information in some selected cases. In fact, high PR expression has a statistically significant association with longer overall survival, thereby providing useful prognostic data. These results suggest that PR positivity may represent a positive prognostic factor for recurrence and survival in LMS, similarly to previously published data (29-31).

Furthermore, Zhang et al. evaluated the Ki-67 index within the same patient population, and found it to be significantly higher in LMS than in LM and STUMP. In particular, more than $45 \%$ of LMS cases had a Ki-67 index of more than $66 \%$ compared with $29 \%$ of cases with an index of less than $33 \%$. In contrast, almost $95 \%$ of all other types of smooth-muscle cell tumors were found to have a Ki67 index less than $30 \%$ (30). On the basis of these data, the authors proposed $33 \%$ as a $\mathrm{Ki}-67$ index cut-off useful for differentiating among LMS and other types of uterine smooth-muscle tumor.

In summary, no single marker may be considered exhaustive and sufficient to separate LMS from other variants but it would be appropriate to analyze an immunohistochemical panel evaluating several biomarkers such as PR, ER, Ki-67 and p53, especially in case of uterine smooth-muscle tumors with ambiguous or borderline histological features $(30,31)$.

\section{STUMP Versus Inflammatory Myofibroblastic Tumor: The Role of ALK Rearrangement}

An emerging issue is that of the morphological and immunohistochemical overlap between uterine inflammatory myofibroblastic tumors (IMT) and STUMPs, especially those with myxoid features. IMT is a rare malignant tumor characterized by the presence of myofibroblastic spindle cells, usually surrounded by a lymphoplasmacytic inflammatory infiltrate (32). The diagnosis of IMT is often neglected because of its rarity, especially when IMT is pauciinflammatory and may be confused with benign myxoid LM and malignant myxoid or inflammatory LMS (33). In 2015, the MD Anderson group described the first case of a patient with anaplastic lymphoma kinase (ALK)-rearranged metastatic myxoid neoplasm who was treated with targeted ALK-inhibitor therapy. In the presentation, the diagnosis of myxoid neoplasm was mistaken for STUMP (34).

Devereaux et al. recently analyzed 60 tumors diagnosed as STUMP from 2007 to 2017 and found 14\% of STUMPs to be morphologically compatible with IMTs. These uterine and cervical tumors were found to be $A L K$ rearrangementpositive IMTs by immunohistochemistry and fluorescence in situ hybridization; based on these findings, the authors highlighted the risk of overdiagnosing STUMP and misdiagnosing IMT (35). Further investigations are needed to better define the potential role of $A L K$ in identifying patients with ALK rearrangement-positive tumors.

\section{Clinical Presentation}

Clinical features associated with STUMP resemble those of ordinary LM. In particular, the signs and symptoms of STUMP are abnormal uterine bleeding, pelvic mass, pelvic pain, symptoms of anemia such as fatigue, pale skin and tachycardia, or a combination thereof (8). No specific risk factors have been associated with the diagnosis of STUMP (4). In a retrospective study by Guntupalli et al., no race/ethnicity differences were found between patients who developed STUMP and did or did not develop recurrence (36).

Median age at diagnosis appears to be around 50 years, in concordance with the median age of presentation in LMS and LM (7). Nevertheless, there are some remarkable exceptions to this general rule, as indicated in a recent case report of a 20-year-old woman with STUMP (37). A quite surprising remark about the age of presentation is that patients affected by cancer relapse are younger when compared with those with an uneventful follow-up. In Ip's study, the mean age of diagnosis of patients with recurrent disease was 43.9 years compared with 44.5 years in patients without recurrence (5). Similarly, in another study, the mean age of patients was 33.7 versus 43.9 years, respectively (36). 
Table I. Published data about recurrent uterine smooth-muscle tumors of uncertain malignant potential (STUMP).

\begin{tabular}{|c|c|c|c|c|c|c|c|c|c|}
\hline Source & Atypia & $\begin{array}{l}\mathrm{MF} / 10 \\
\mathrm{HPF}\end{array}$ & $\mathrm{CTCN}$ & Surgery & $\begin{array}{l}\text { Time to } \\
\text { recurrence } \\
\text { (months) }\end{array}$ & $\begin{array}{l}\text { Sites } \\
\text { of } \\
\text { recurrence }\end{array}$ & $\begin{array}{l}\text { Histology } \\
\quad \text { of } \\
\text { recurrence }\end{array}$ & $\begin{array}{l}\text { Treatment } \\
\text { of } \\
\text { recurrence }\end{array}$ & $\begin{array}{l}\text { Overall survival } \\
\text { (after initial } \\
\text { diagnosis), months }\end{array}$ \\
\hline Ip et al. (5) & $\begin{array}{c}\text { Multifocal, } \\
2-3\end{array}$ & 4 & None & $\mathrm{H}$ & 51 & Pelvis & LMS & $\begin{array}{c}\text { Surgery and } \\
\text { adjuvant radiation } \\
\text { therapy }\end{array}$ & Alive at 74 \\
\hline Ip et al. (5) & $\begin{array}{c}\text { Multifocal, } \\
2-3\end{array}$ & 5 & None & $\mathrm{H}$ & 15 & $\begin{array}{l}\text { Pelvis and } \\
\text { lymph nodes }\end{array}$ & LMS & $\begin{array}{l}\text { Surgery and } \\
\text { adjuvant } \\
\text { chemotherapy }\end{array}$ & Alive at 40 \\
\hline Atkins et al. (24) & $1-2$ & 3 & None & NA & NA & $\begin{array}{l}\text { Pelvis and } \\
\text { lymph nodes }\end{array}$ & STUMP & $\begin{array}{l}\text { Surgery and } \\
\text { medroxyprogeste- } \\
\text { rone acetate }\end{array}$ & Alive at 36 \\
\hline Shapiro et al. (43) & $\begin{array}{c}\text { Multifocal, } \\
2-3\end{array}$ & 15 & None & $\mathrm{H}$ & 51 & $\begin{array}{c}\text { Bone (After } 17 \\
\text { mo, lung) }\end{array}$ & LMS & Surgery & Alive at 68 \\
\hline Berretta et al. (42) & $2-3$ & $<10$ & None & $\mathrm{H}$ & 108 & Lung & STUMP & $\begin{array}{l}\text { Surgery; after one } \\
\text { year, PD: gonado- } \\
\text { tropin-releasing } \\
\text { hormone agonists } \\
\text { and an aromatase } \\
\text { inhibitor }\end{array}$ & $\begin{array}{l}\text { Alive at more } \\
\text { than } 108\end{array}$ \\
\hline Atkins et al. (24) & 1 & 1 & Yes & NA & NA & Liver & STUMP & Surgery & Alive at 40 \\
\hline Atkins et al. (24) & 1 & 4 & Yes & NA & NA & Liver & STUMP & Surgery & NA \\
\hline Amant et al. (20) & None & 3 & Yes & $\mathrm{H}$ & 48 & Pelvis & LMS & $\begin{array}{l}\text { Surgery and adjuvant } \\
\text { medroxyprogeste- } \\
\text { rone acetate }\end{array}$ & $\begin{array}{l}\text { Alive at more } \\
\text { than } 48\end{array}$ \\
\hline Bell et al. (2) & None & 1 & None & $\mathrm{H}$ & NA & $\begin{array}{c}\text { Small bowel, } \\
\text { omentum, } \\
\text { peritoneum }\end{array}$ & STUMP & $\begin{array}{l}\text { Surgery and } \\
\text { adjuvant } \\
\text { radiotherapy }\end{array}$ & Alive at 29 \\
\hline Bell et al. (2) & 2 & 1 & None & $\mathrm{H}$ & 120 & Lung, mesentery & STUMP & Surgery & Dead after than 120 \\
\hline Bell et al. (2) & 2 & 2 & None & $\mathrm{H}$ & 72 & Lung & STUMP & $\begin{array}{c}\text { Surgery; after } \\
7 \text { years, } \\
\text { pulmonary relapse }\end{array}$ & Alive at 156 \\
\hline Bell et al. (2) & 2 & 6 & None & $\mathrm{H}$ & 12 & Pelvis & STUMP & $\begin{array}{c}\text { Surgery; after } \\
8 \text { years, lung } \\
\text { metastases }\end{array}$ & Dead at 90 \\
\hline Bell et al. (2) & 2 & 3 & None & M & 48 & Pelvis & STUMP & Surgery & Alive at 60 \\
\hline Bell et al. (2) & 3 & 2 & None & $\mathrm{H}$ & 24 & $\begin{array}{l}\text { Pelvis and } \\
\text { peritoneum }\end{array}$ & STUMP & $\begin{array}{l}\text { Debulking therapy } \\
\text { and adjuvant } \\
\text { chemoradiotherapy }\end{array}$ & Alive at 60 \\
\hline Bell et al. (2) & 3 & Rare & Yes & $\mathrm{H}$ & 36 & Lung & STUMP & $\begin{array}{c}\text { Surgery and } \\
\text { adjuvant } \\
\text { chemotherapy }\end{array}$ & Dead after 67 \\
\hline Bell et al. (2) & 3 & 1 & Yes & $\mathrm{H}$ & 128 & Bone & STUMP & Surgery & Dead after 204 \\
\hline Bell et al. (2) & 3 & 1 & Yes & $\mathrm{H}$ & 24 & Lung & STUMP & $\begin{array}{l}\text { Surgery and } \\
\text { adjuvant } \\
\text { chemotherapy }\end{array}$ & Dead after 60 \\
\hline Bell et al. (2) & 2 & 4 & Yes & $\mathrm{H}$ & 68 & Lung & STUMP & $\begin{array}{l}\text { Surgery and } \\
\text { adjuvant } \\
\text { chemotherapy }\end{array}$ & Alive at 183 \\
\hline Bell et al. (2) & 2 & 3 & Yes & M & 10 & Pelvis & STUMP & Surgery & NA \\
\hline Bell et al. (2) & 2 & 3 & Yes & M & 60 & Pelvis & STUMP & Surgery & Alive at 84 \\
\hline Bell et al. (2) & 2 & 3 & Yes & $\mathrm{H}$ & 37 & Pelvis & STUMP & NA & Alive at 53 \\
\hline Bacanakgil et al. (44) & $2-3$ & 6 & None & M & 11 & Pelvis & NA & $\begin{array}{c}\text { Surgery and } \\
\text { adjuvant } \\
\text { chemotherapy }\end{array}$ & NA \\
\hline Basaran et al. (45) & 2 & $2-5$ & Yes & M & 46 & Pelvis & LMS & Surgery & Dead after 95 \\
\hline Basaran et al. (45) & 2 & $<2$ & Yes & M & 25 & Pelvis & LMS & Surgery & Alive at 49 \\
\hline Veras et al. (46) & $1-2$ & 1 & None & NA & 6 & Lung, liver, bone & LMS & NA & NA \\
\hline Veras et al. (46) & 2 & 1 & None & NA & 26 & Lung & STUMP & NA & NA \\
\hline
\end{tabular}


Table I. Continued

\begin{tabular}{|c|c|c|c|c|c|c|c|c|c|}
\hline Source & Atypia & $\begin{array}{c}\mathrm{MF} / 10 \\
\mathrm{HPF}\end{array}$ & $\mathrm{CTCN}$ & Surgery & $\begin{array}{r}\text { Time } \\
\text { recurr } \\
\text { (mon }\end{array}$ & $\begin{array}{l}\text { Sites } \\
\text { of } \\
\text { recurrence }\end{array}$ & $\begin{array}{l}\text { Histology } \\
\text { of } \\
\text { recurrence }\end{array}$ & $\begin{array}{l}\text { Treatment } \\
\text { of } \\
\text { recurrence }\end{array}$ & $\begin{array}{l}\text { Overall survival } \\
\text { (after initial } \\
\text { diagnosis), months }\end{array}$ \\
\hline Veras et al. (46) & 2 & 2 & None & NA & 7 & $\begin{array}{l}\text { Lymph nodes, } \\
\text { ovary, omentum, } \\
\text { small bowel, } \\
\text { pelvic wall }\end{array}$ & STUMP & NA & NA \\
\hline Veras et al. (46) & $1-2$ & 2 & None & NA & 157 & $\begin{array}{l}\text { Omentum, } \\
\text { peritoneum, small } \\
\text { bowel, colon, } \\
\text { mesentery }\end{array}$ & STUMP & NA & Alive at 283 \\
\hline Veras et al. (46) & 2 & 2 & None & NA & 194 & $\begin{array}{l}\text { Bone, pelvis, } \\
\text { ureter }\end{array}$ & STUMP & NA & Alive at 278 \\
\hline Veras et al. (46) & $1-2$ & 2 & None & NA & 109 & $\begin{array}{l}\text { Lung, } \\
\text { retroperitoneum, } \\
\text { adnexa }\end{array}$ & STUMP & NA & Alive at 201 \\
\hline Veras et al. (46) & $1-2$ & 8 & None & NA & 115 & Bone, pelvis & STUMP & NA & NA \\
\hline Veras et al. (46) & 2 & 1 & None & NA & 30 & Bone, lung & STUMP & NA & NA \\
\hline Guntupalli et al. (36) & NA & NA & NA & $\mathrm{H}$ & 13 & Lung, pelvis & STUMP & $\begin{array}{l}\text { Surgery, medroxy- } \\
\text { progesterone acetate }+ \\
\text { gonadotropin-releasing } \\
\text { hormone agonists }\end{array}$ & Alive at 157 \\
\hline Guntupalli et al. (36) & NA & NA & NA & $\mathrm{H}$ & 68 & Retroperitoneum & STUMP & NA & Alive at 106 \\
\hline Guntupalli et al. (36) & NA & NA & NA & $\mathrm{H}$ & 47 & Retroperitoneum & LMS & $\begin{array}{l}\text { Surgery and adjuvant } \\
\text { chemotherapy } \\
\text { (doxorubicin + cisplatin) }\end{array}$ & Alive at 150 \\
\hline Sung et al. (47) & 2 & 2 & None & M & 22 & Pelvis & STUMP & Surgery & Alive at 35 \\
\hline Ly et al. (48) & 2 & 1 & None & $\mathrm{H}$ & 87 & Retroperitoneum & STUMP & NA & NA \\
\hline Yoon et al. (49) & $2-3$ & $<10$ & None & M & 6 & Pelvis & LMS & $\begin{array}{c}\text { Surgery and adjuvant } \\
\text { chemotherapy }\end{array}$ & Alive at 36 \\
\hline Gupta et al. (4) & $2-3$ & 1 & None & M & 53 & Pelvis & LMS & $\begin{array}{l}\text { Surgery and adjuvant } \\
\text { chemotherapy } \\
\text { (gemcitabine - docetaxel) }\end{array}$ & Alive at 101 \\
\hline Gupta et al. (4) & $2-3$ & 1 & None & M & 29 & Pelvis & STUMP & Surgery & Alive at 99 \\
\hline Gupta et al. (4) & $2-3$ & 5 & None & $\mathrm{H}$ & 29 & Pelvis & NA & NA & NA \\
\hline Gupta et al. (4) & $2-3$ & 1 & None & $\mathrm{H}$ & 92 & Pelvis, bladder & LMS & $\begin{array}{l}\text { Neoadjuvant } \\
\text { chemotherapy } \\
\text { (gemcitabine - } \\
\text { docetaxel) + surgery }\end{array}$ & Alive at 101 \\
\hline Gupta et al. (4) & $2-3$ & 1 & None & $\mathrm{H}$ & 60 & Lung & $\mathrm{y}$ & $\begin{array}{c}\text { Neoadjuvant } \\
\text { chemotherapy } \\
\text { (ifosfamide and } \\
\text { doxorubicin) and } \\
\text { radiotherapy; after one } \\
\text { year, brain relapse treated } \\
\text { with debulking therapy } \\
\text { and radiotherapy }\end{array}$ & Alive at 113 \\
\hline Gupta et al. (4) & $2-3$ & 3 & None & $\mathrm{H}$ & 2 & Lung & NA & Surgery & Alive at 48 \\
\hline Gupta et al. (4) & 1 & 1 & NA & $\mathrm{H}$ & 117 & Pelvis, lung, pleura & NA & $\begin{array}{c}\text { Surgery and aromatase } \\
\text { inhibitor }\end{array}$ & Alive at 124 \\
\hline Gupta et al. (4) & $2-3$ & 7 & NA & $\mathrm{H}$ & 2 & Lung, bone & $\begin{array}{l}\mathrm{C} \\
\mathrm{m} \\
\mathrm{tr}\end{array}$ & $\begin{array}{l}\text { Chemotherapy (ifosfamide } \\
\text { and doxorubicin) and } \\
\text { radiotherapy. After } 32 \\
\text { months, pelvic recurrence } \\
\text { treated with gemcitabine - } \\
\text { docetaxel followed by } \\
\text { an aromatase inhibitor }\end{array}$ & Alive at 57 \\
\hline
\end{tabular}

NA: Not available; CTCN: coagulative tumor cell necrosis; H: hysterectomy; M: myomectomy; LMS: leiomyosarcoma. S: solitary; M: multiple; Intra: intraluminal; Extra: extraluminal; NED: no evidence of disease. 
Most STUMPs are detected with transvaginal ultrasound and endometrial biopsy $(5,11)$; imaging techniques such as computed tomographic scan and magnetic resonance imaging (MRI) are considered useful to provide additional information regarding the size, density and relationship with surrounding structures of the pelvis $(5,6,10)$.

\section{Myomectomy Versus Hysterectomy: Balancing Risk and Fertility}

The term 'uncertain malignant potential' is particularly appropriate if we look at the clinical behavior and course of STUMP. No standard guidelines have been approved for the treatment of STUMP, and the strategy to be followed for the management of the disease remains controversial. Moreover, this clinical 'crossroad' is further complicated by a frequent indolent behavior and a prolonged survival rate (8). Hysterectomy is currently considered the gold standard and it is especially recommended for women who have completed their childbearing, for whom maintenance of fertility is not a major issue. On the other hand, the choice between myomectomy and hysterectomy represents an extremely important issue in the management of STUMP in young women balancing the risk of recurrence and the preservation of fertility (10). As reported in Table I, among 35 patients diagnosed with STUMP and initially treated with surgery, 10 had undergone myomectomy $(10 / 35,29 \%)$, while $25(25 / 35,71 \%)$ underwent hysterectomy. The decision about how to treat the disease in premenopausal women with fertility desire should include a risk-benefit discussion with the patient, taking into account the histological features of the tumor, the psychological impact of hysterectomy in young women, pregnancy outcomes in the case of myomectomy and the ambiguous malignancy of STUMP (8). In the case of myomectomy, close surveillance should be mandatory (37). Patients should also be aware of the realistic impact of fertility-sparing approaches; a recent study highlights the feasibility of these techniques despite the not insignificant risk of recurrence (38).

In 2012, Vilos et al. conducted a literature research on patients with STUMP who underwent myomectomy (10) summarizing findings from 14 articles and a total of 76 patients. In this context, it is interesting to note that 5 out of $76(6.6 \%)$ patients who opted for myomectomy experienced relapse, with follow-up ranging from 1 to 216 months. Furthermore, 1 out of the 76 patients $(1.3 \%)$ died because of the recurrence of STUMP (10), suggesting again the heterogeneous nature of the disease and the difficulty in determining the true malignant potential of STUMP. As indicated by Peters et al., some STUMPs have an aggressive clinical course, in contrast with the protracted clinical course of the majority of these tumors, which also holds true in the case of a relapse (39).

\section{Follow-up}

Most STUMP relapses occur after 5 years of diagnosis and the lack of data makes it hard to draw definitive conclusions regarding an appropriate follow-up program. Guntupalli et al. proposed monitoring patients affected by previous STUMP with close follow-up considering the unpredictable behavior of the disease and the possibility of recurring as uterine LMS (36). This is in accordance with other authors, as Ip et al. suggested a follow-up interval of 6 months for the first 5 years followed by annual surveillance for a period of at least 5 additional years (8).

Although criteria for the follow-up remain elusive, a reasonable approach would suggest at least annual surveillance to extend until 10 years. Lungs are found to be frequently involved as a metastatic site, and this finding supports careful chest monitoring by annual chest radiography and eventually chest computed tomographic scan in the case of symptomatic patients.

Lin et al. recently compared the diagnostic accuracy of contrast-enhanced MRI and diffusion-weighted MRI in the differentiation between uterine LMS/STUMP and benign LM. Contrast-enhanced MRI showed better accuracy than diffusion-weighted MRI, and this technique may provide useful additional information in diagnosis as well as in identifying pelvic recurrence (40).

\section{Treatment of Relapse}

The risk to recur is one of the hallmarks of uterine STUMP. The type of surgery does not seem to influence the type and the time of recurrence, characterized by remarkable differences between the cases reported in the literature. The reported STUMP recurrence rate ranges between $8.7 \%$ and $11 \%$, and relapses may be histologically consistent with the diagnosis of STUMP or LMS $(2,6,8,9)$.

Time to recurrence ranges from 2 to 194 months in the published data about recurrent STUMP. These extremes bear witness to the unpredictable behavior of STUMP and the spectrum of possibilities of this neoplasm. The mean value of 54 months seems to be in accordance with the frequently indolent behavior associated with STUMP as suggested in previous studies $(8,36)$.

Although standard guidelines for treatment are not available, the standard strategy for recurrence remains surgical treatment (8). Considerable heterogeneity has been reported at the time of relapse treatment $(8,20,36)$. Few data are available in the literature about the potential role of adjuvant therapy and systemic treatment and pelvic irradiation are of no proven value in this setting (2). Moreover, the choice of adjuvant chemotherapy does not seem to be guided by histological features at diagnosis, time to recurrence or histopathology at the time of recurrence. 
This therapeutic modality, in fact, seems to be primarily affected by the physician's preferences, and the variety of treatment approaches make it difficult to define an unambiguous line of action.

Bell et al. reported 4 cases of recurrent STUMP treated with surgery and additional chemotherapy; one patient underwent surgery and received adjuvant radiochemotherapy (2). Doxorubicin and cisplatin were found to be the most widely used chemotherapeutic agents in the literature, in both adjuvant and palliative settings $(5,36)$.

There have been reports of patients treated with endocrine therapy based on progesterone, aromatase inhibitors or gonadotropin-releasing hormone analogues (5, 20, 36). Atkins et al. reported a case of peritoneal and lymph nodes relapse treated with progesterone after tumor debulking. The patient was disease-free after 36 months of follow-up (24). Further investigations would be necessary to establish the true efficacy of progesterone, with a view to using a progesterone-releasing intrauterine device after myomectomy in premenopausal women (41).

Berretta et al. published a case series of 3 cases of STUMP in which one patient developed lung recurrence after 9 years and underwent surgery. The patient had a second recurrence after 12 months and was treated with gonadotropin-releasing hormone agonists and an aromatase inhibitor (42).

The prognostic impact of additional treatment is currently not defined, and no recommendable strategies are available. No satisfying data about adjuvant treatment exist, be it radiotherapy, chemotherapy or endocrine therapy, and authors agree on recommending treatment on an individual basis $(5,20,36,50)$.

In our literature search, 15 out of 46 patients $(33 \%)$ experienced local relapse, with the pelvic area as the only involved site. The most common distant metastatic sites were found to be lung $(15 / 46,33 \%)$, bone $(7 / 46)$, liver and peritoneum. One patient experienced small bowel metastasis, and another one colon recurrence. One case of brain metastases was reported. In 40 patients, recurrence was confirmed by histological examination, and in 11 out of 40 patients ( $25 \%$ of cases), histology was consistent with LMS. Treatment of recurrence was available in 34 out of 46 patients. Thirty-one women affected by recurrent STUMP underwent upfront surgery, while 2 cases were treated with neoadjuvant chemotherapy followed by surgery. In 13 women, surgery was the only treatment performed. Adjuvant chemotherapy was performed in nine out of 31 patients $(29 \%)$, while 4 patients received hormonal therapy.

For 36 out of 46 patients, it was possible to define the survival after the initial diagnosis of STUMP. The mean survival from initial diagnosis was 101 months (range=29283 months) (Table I).

\section{Conclusion}

Uterine STUMP represents a therapeutic dilemma, and further observational data would be required to reach a consensus concerning management balancing the indolent clinical course against the malignant, even lethal, potential. A multidisciplinary approach is mandatory, and we encourage the collection of larger series in order to obtain the greatest possible number of data about this rare entity.

A future perspective may be to identify the molecular basis of STUMP using molecular biology techniques. The identification of key genes directly involved in the carcinogenesis of STUMP may suggest novel opportunities in the management of the disease and provide further information in understanding the process of carcinogenesis. Furthermore, recent findings on ALK-rearranged IMT, misdiagnosed as STUMP at the time of first surgery, suggest an accurate characterization of recurrence (35). On the basis of these findings, we propose that all pathology slides should be reviewed by experienced gynecological pathologists.

Recurrent uterine STUMPs represent a diagnostic, therapeutic and clinical challenge, and the lack of consensus in multiple "areas" of the management of the disease requires additional efforts considering the paucity of data currently available in the literature and the extreme rarity of this disease.

\section{Conflicts of Interest}

All Authors declare they have no conflicts of interest in regard to this study.

\section{Authors' Contributions}

Rizzo A: Made substantial contributions to conception of the study and drafted the article; Ricci AD: made substantial contributions to conception of the study and was involved in revising the article critically for important intellectual content; Saponara M: gave final approval of the version to be published; De Leo A: revised the article; Perrone AM: gave final approval of the version to be published; De Iaco P: helped to draft the article and revised the article; Pantaleo MA: was involved in revising the article critically for important intellectual content and gave final approval of the version to be published; Nannini M: made substantial contributions to conception of the study and gave final approval of the version to be published.

\section{Acnowledgements}

This work was supported by the Department of Experimental, Diagnostic and Specialty Medicine, DIMES, S. Orsola-Malpighi University Hospital, Bologna, Italy.

\section{References}

1 Kempson RL: Sarcoma and related neoplasms. In: Norris HJ, Heritig AT, Abell MR (eds.). The Uterus. Baltimore: Williams and Wilkins; 1973. 
2 Bell SW, Kempson RL and Hendrickson MR: Problematic uterine smooth muscle neoplasms. A clinicopathologic study of 213 cases. Am J Surg Pathol 18(6): 535-558, 1994. PMID: 8179071.

3 Kurman R, Carcangiu M, Herrington C and Young RH: World Health Organisation Classification of Tumors of Female Reproductive Organs, $4^{\text {th }}$ edn. Lyon Fr Int Agency Res Cancer Press; 2014

4 Gupta M, Laury AL, Nucci MR and Quade BJ: Predictors of adverse outcome in uterine smooth muscle tumours of uncertain malignant potential (STUMP): a clinicopathological analysis of 22 cases with a proposal for the inclusion of additional histological parameters. Histopathology 73(2): 284-298, 2018. PMID: 29537683. DOI: 10.1111/his.13515

5 Ip PPC, Cheung ANY and Clement PB: Uterine smooth muscle tumors of uncertain malignant potential (STUMP): a clinicopathologic analysis of 16 cases. Am J Surg Pathol 33(7): 992-1005, 2009. PMID: 17667546. DOI: 10.1097/PAS.0b0 $13 \mathrm{e} 3181 \mathrm{a} 02 \mathrm{~d} 1 \mathrm{c}$

6 Dall'Asta A, Gizzo S, Musarò A, Quaranta M, Noventa M, Migliavacca C, Sozzi G, Monica M, Mautone D and Berretta R: Uterine smooth muscle tumors of uncertain malignant potential (STUMP): pathology, follow-up and recurrence. Int J Clin Exp Pathol 7(11): 8136-8142, 2014. PMID: 25550862.

7 Ip PPC and Cheung ANY: Pathology of uterine leiomyosarcomas and smooth muscle tumours of uncertain malignant potential. Best Pract Res Clin Obstet Gynaecol 25(6): 691-704, 2011. PMID: 21865091. DOI: 10.1016/j.bpobgyn.2011.07.003

8 Ip PPC, Tse KY and Tam KF: Uterine smooth muscle tumors other than the ordinary leiomyomas and leiomyosarcomas: a review of selected variants with emphasis on recent advances and unusual morphology that may cause concern for malignancy. Adv Anat Pathol 17(2): 91-112, 2010. PMID: 20179432. DOI: 10.1097/PAP.0b013e3181 cfb901

9 O'Neill CJ, McBride HA, Connolly LE and McCluggage WG: Uterine leiomyosarcomas are characterized by high p16, p53 and MIB1 expression in comparison with usual leiomyomas, leiomyoma variants and smooth muscle tumours of uncertain malignant potential. Histopathology 50(7): 851-858, 2007. PMID: 17543074. DOI: 10.1111/j.1365-2559.2007.02699.x

10 Vilos GA, Marks J, Ettler HC, Vilos AG, Prefontaine M and Abu-Rafea B: Uterine smooth muscle tumors of uncertain malignant potential: diagnostic challenges and therapeutic dilemmas. Report of 2 cases and review of the literature. J Minim Invasive Gynecol 19(3): 288-295, 2012. PMID: 22546421. DOI: 10.1016/j.jmig.2011.12.025

11 Casali PG, Abecassis N, Aro HT, Bauer S, Bauer S, Biagini R, Bielack S, Bonvalot S, Boukovinas I, Bovee JVMG, Brodowicz T, Broto JM, Buonadonna A, De Álava E, Dei Tos AP, Del Muro XG, Dileo P, Eriksson M, Fedenko A, Ferraresi V, Ferrari A, Ferrari S, Frezza AM, Gasperoni S, Gelderblom H, Gil T, Grignani G, Gronchi A, Haas RL, Hassan B, Hohenberger P, Issels R, Joensuu H, Jones RL, Judson I, Jutte P, Kaal S, Kasper B, Kopeckova K, Krákorová DA, Le Cesne A, Lugowska I, Merimsky O, Montemurro M, Pantaleo MA, Piana R, Picci P, Piperno-Neumann S, Pousa AL, Reichardt P, Robinson MH, Rutkowski P, Safwat AA, Schöffski P, Sleijfer S, Stacchiotti S, Sundby Hall K, Unk M, Van Coevorden F, van der Graaf WTA, Whelan J, Wardelmann E, Zaikova O and Blay JY; ESMO Guidelines Committee and EURACAN: Soft tissue and visceral sarcomas: ESMO-EURACAN Clinical Practice Guidelines for diagnosis, treatment and follow-up. Ann Oncol 29(Suppl 4): iv51iv67, 2018. PMID: 30285214. DOI: 10.1093/annonc/mdy096

12 Hanby AM, Walker C, Tavassoli FA and Devilee P: Pathology and Genetics: Tumours of the Breast and Female Genital Organs. WHO Classification of Tumours series - volume IV. Lyon, France: IARC Press; 2003.

13 Oliva E: Practical issues in uterine pathology from banal to bewildering: The remarkable spectrum of smooth muscle neoplasia. Mod Pathol 29(Suppl 1): S104-120, 2016. PMID: 26715170. DOI: $10.1038 /$ modpathol.2015.139

14 Prayson RA and Hart WR: Mitotically active leiomyomas of the uterus. Am J Clin Pathol 97(1): 14-20, 1992. PMID: 1728856. DOI: $10.1093 / \mathrm{ajcp} / 97.1 .14$

15 Walker CL and Stewart EA: Uterine fibroids: the elephant in the room. Science 308(5728): 1589-1592, 2005. PMID: 15947177. DOI: $10.1126 /$ science. 1112063

16 Raposo MI, Meireles C, Cardoso M, Ormonde M, Ramalho C, Pires $\mathrm{M}$, Afonso $\mathrm{M}$ and Petiz A: Benign metastasizing leiomyoma of the uterus: rare manifestation of a frequent pathology. Case Rep Obstet Gynecol 2018: 5067276, 2018. PMID: 30510824. DOI: 10.1155/2018/5067276

17 Barnas E, Ksiazek M, Ras R, Skret A, Skret-Magieroo J and Dmoch-Gajzlerska E: Benign metastasizing leiomyoma: A review of current literature in respect to the time and type of previous gynecological surgery. PLoS One 12(4): e0175875, 2017. PMID: 28426767. DOI: 10.1371/journal.pone.0175875

18 Patton KT, Cheng L, Papavero V, Blum MG, Yeldandi AV, Adley BP, Luan C, Diaz LK, Hui P and Yang XJ: Benign metastasizing leiomyoma: clonality, telomere length and clinicopathologic analysis. Mod Pathol 19(1): 130-140, 2006. PMID: 16357844. DOI: $10.1038 /$ modpathol.3800504

19 Jo HC and Baek JC: Case of pulmonary benign metastasizing leiomyoma from synchronous uterine leiomyoma in a postmenopausal woman. Gynecol Oncol Rep 26: 33-36, 2018. PMID: 30225333. DOI: 10.1016/j.gore.2018.08.009

20 Amant F, Moerman P and Vergote I: Report of an unusual problematic uterine smooth muscle neoplasm, emphasizing the prognostic importance of coagulative tumor cell necrosis. Int $\mathbf{J}$ Gynecol Cancer 15(6): 1210-1212, 2005. PMID: 16343216. DOI: $10.1111 / \mathrm{j} .1525-1438.2005 .00183 . \mathrm{x}$

21 Lim D, Alvarez T, Nucci MR, Gilks B, Longacre T, Soslow RA and Oliva E: Interobserver variability in the interpretation of tumor cell necrosis in uterine leiomyosarcoma. Am J Surg Pathol 37(5): 650-658, 2013. PMID: 23552382. DOI: 10.1097/PAS.0b0 $13 \mathrm{e} 3182851162$

22 Mittal K and Demopoulos RI: MIB-1 (Ki-67), p53, estrogen receptor, and progesterone receptor expression in uterine smooth muscle tumors. Hum Pathol 32(9): 984-987, 2001. PMID: 11567229. DOI: 10.1053/hupa.2001.27113

23 Dastranj Tabrizi A, Ghojazadeh M, Thagizadeh Anvar H, Vahedi A, Naji S, Mostafidi E and Berenjian S: Immunohistochemical profile of uterine leiomyoma with bizarre nuclei; comparison with conventional leiomyoma, smooth muscle tumors of uncertain malignant potential and leiomyosarcoma. Adv Pharm Bull 5(Suppl 1): 683-687, 2015. PMID: 26793616. DOI: 10.15171/apb.2015.093

24 Atkins KA, Arronte N, Darus CJ and Rice LW: The Use of p16 in enhancing the histologic classification of uterine smooth muscle tumors. Am J Surg Pathol 32(1): 98-102, 2008. PMID: 18162776. DOI: 10.1097/PAS.0b013e3181574d1e 
25 Raspollini MR, Amunni G, Villanucci A, Boddi V, Simoni A, Taddei A and Taddei GL: Estrogen and progesterone receptors expression in uterine malignant smooth muscle tumors: correlation with clinical outcome. J Chemother 15(6): 596-602, 2003. PMID: 14998087. DOI: 10.1179/joc.2003.15.6.596

26 Akhan SE, Yavuz E, Tecer A, Iyibozkurt CA, Topuz S, Tuziali S, Benjisu E and Berkman S: The expression of Ki-67, p53, estrogen and progesterone receptors affecting survival in uterine leiomyosarcomas. A clinicopathologic study. Gynecol Oncol 99(1): 36-42, 2005. PMID: 15992918. DOI: 10.1016/j.ygyno.2005.05.019

27 Hewedi IH, Radwan NA and Shash LS: Diagnostic value of progesterone receptor and p53 expression in uterine smooth muscle tumors. Diagn Pathol 7: 1, 2012. PMID: 22217299. DOI: 10.1186/1746-1596-7-1

28 Davidson B, Kjæreng ML, Førsund M, Danielsen HE, Kristensen GB and Abeler VM: Progesterone receptor expression is an independent prognosticator in FIGO stage I uterine leiomyosarcoma. Am J Clin Pathol 145(4): 449-458, 2016. PMID: 27149024. DOI: 10.1093/ajcp/aqw030

29 O'Cearbhaill R, Zhou Q, Iasonos A, Soslow RA, Leitao MM, Aghajanian $\mathrm{C}$ and Hensley ML: Treatment of advanced uterine leiomyosarcoma with aromatase inhibitors. Gynecol Oncol 116(3): 424-429, 2010. PMID: 19932916. DOI: 10.1016/j.ygyno. 2009.10.064

30 Zhang Q, Kanis MJ, Ubago J, Liu D, Scholtens DM, Strohl AE, Lurain JR, Shahabi S, Kong B and Wei JJ: The selected biomarker analysis in 5 types of uterine smooth muscle tumors. Hum Pathol 76: 17-27, 2018. PMID: 29258902. DOI: 10.1016/j.humpath.2017.12.005

31 Leitao MM, Hensley ML, Barakat RR, Aghajanian C, Gardner GJ, Jewell EL, O'Cearbhaill $\mathrm{R}$ and Soslow RA: Immunohistochemical expression of estrogen and progesterone receptors and outcomes in patients with newly diagnosed uterine leiomyosarcoma. Gynecol Oncol 124(3): 558-562, 2012. PMID: 22085894. DOI: $10.1016 /$ j.ygyno.2011.11.009

32 Lovly CM, Gupta A, Lipson D, Otto G, Brennan T, Chung CT, Borinstein SC, Ross JS, Stephens PJ, Miller VA and Coffin CM: Inflammatory myofibroblastic tumors harbor multiple potentially actionable kinase fusions. Cancer Discov 4(8): 889-895, 2014. PMID: 24875859. DOI: 10.1158/2159-8290.CD-14-0377

33 Fraggetta F, Doglioni C, Scollo P, Pecciarini L, Ippolito M, Amico P, Pelosi G and Ponzoni M: Uterine inflammatory myofibroblastic tumor in a 10 -year-old girl presenting as polypoid mass. J Clin Oncol 33(2): e7-e10, 2015. PMID: 24590652. DOI: $10.1200 / \mathrm{JCO} .2013 .48 .8304$

34 Subbiah V, McMahon C, Patel S, Zinner R, Silva EG, Elvin JA, Subbiah IM, Ohaji C, Ganeshan DM, Anand D, Levenback CF, Berry J, Brennan T, Chmielecki J, Chalmers ZR, Mayfield J, Miller VA, Stephens PJ and Ross JS, Ali SM: STUMP un"stumped": anti-tumor response to anaplastic lymphoma kinase (ALK) inhibitor based targeted therapy in uterine inflammatory myofibroblastic tumor with myxoid features harboring DCTN1-ALK fusion. J Hematol Oncol 8: 66, 2015. PMID: 26062823. DOI: 10.1186/s13045-015-0160-2

35 Devereaux KA, Kunder CA and Longacre TA: ALK-rearranged Tumors Are Highly Enriched in the STUMP Subcategory of Uterine Tumors. Am J Surg Pathol 43(1): 64-74, 2019. PMID: 29794871. DOI: 10.1097/PAS.0000000000001083

36 Guntupalli SR, Ramirez PT, Anderson ML, Milam MR, Bodurka DC and Malpica A: Uterine smooth muscle tumor of uncertain malignant potential: a retrospective analysis. Gynecol Oncol 113(3): 324-326, 2009. PMID: 19342083. DOI: 10.1016/j.ygyno. 2009.02.020

37 Hughes L, Roex A and Parange A: STUMP, a surprise finding in a large fibroid uterus in a 20-year-old woman. Int J Womens Health 10: 211-214, 2018. PMID: 29765254. DOI: 10.2147/ IJWH.S 153838

38 Şahin H, Karatas F, Coban G, Ozen O, Erdem O, Onan MA and Ayhan A: Uterine smooth muscle tumor of uncertain malignant potential: fertility and clinical outcomes. J Gynecol Oncol 30(4): e54, 2019. PMID: 31074239. DOI: 10.3802/jgo.2019.30.e54

39 Peters WA, Howard DR, Andersen WA and Figge DC: Uterine smooth muscle tumors of uncertain malignant potential. Obstet Gynecol 83(6): 1015-1020, 1994. PMID: 8190416. DOI: 10.1097/00006250-199406000-00023

40 Lin G, Yang L-Y, Huang Y-T, Ng KK, Ng SH, Ueng SH, Chao A, Yen TC, Chang TC and Lai CH: Comparison of the diagnostic accuracy of contrast-enhanced MRI and diffusionweighted MRI in the differentiation between uterine leiomyosarcoma/smooth muscle tumor with uncertain malignant potential and benign leiomyoma. J Magn Reson Imaging 43(2): 333-342, 2016. PMID: 26383110. DOI: 10.1002/jmri.24998

41 Gizzo S, Di Gangi S, Bertocco A, Noventa M, Fagherazzi S, Ancona E, Saccardi C, Patrelli TS, D'Antona D and Nardelli GB: Levonorgestrel intrauterine system in adjuvant tamoxifen treatment: balance of breast risks and endometrial benefits-systematic review of literature. Reprod Sci 21(4): 423-431, 2014. PMID: 24060633. DOI: 10.1177/1933719113503408

42 Berretta R, Rolla M, Merisio C, Giordano G and Nardelli GB: Uterine smooth muscle tumor of uncertain malignant potential: a three-case report. Int J Gynecol Cancer 18(5): 1121-1126, 2014. PMID: 17986240. DOI: 10.1111/j.1525-1438.2007. 01125.x

43 Shapiro A, Ferenczy A, Turcotte R, Bruchim I and Gotlieb WH: Uterine smooth muscle tumor of uncertain malignant potential metastasizing to the humerus as a high-grade leiomyosarcoma. Gynecol Oncol 94(3): 818-820, 2004. PMID: 15350379. DOI: 10.1016/j.ygyno.2004.05.049

44 Bacanakgil BH, Deveci M, Karabuk E and Soyman Z: Uterine smooth muscle tumor of uncertain malignant potential: Clinicopathologic-sonographic characteristics, follow-up and recurrence. World J Oncol 8(3): 76-80, 2017. PMID: 29147439. DOI: $10.14740 /$ wjon $1031 \mathrm{w}$

45 Basaran D, Usubutun A, Salman MC, Narin MA, Boyraz G, Turkmen O, Comert Kimyon G, Karalok A, Bulbul D, Turan T, Ozgul N and Yuce K: The clinicopathological study of 21 cases with uterine smooth muscle tumors of uncertain malignant potential: Centralized review can purify the diagnosis. Int J Gynecol Cancer 28(2): 233-240, 2018. PMID: 29303932. DOI: 10.1097/IGC.0000000000001178

46 Veras E, Zivanovic O, Jacks L, Chiappetta D, Hensley M and Soslow R: 'Low-grade leiomyosarcoma' and late-recurring smooth muscle tumors of the uterus: a heterogenous collection of frequently misdiagnosed tumors associated with an overall favorable prognosis relative to conventional uterine leiomyosarcomas. Am J Surg Pathol 35(11): 1626-1637, 2011. PMID: 21921786. DOI: 10.1097/PAS.0b013e31822b44d2

47 Sung CO, Ahn G, Song SY, Choi YL and Bae DS: Atypical leiomyomas of the uterus with long-term follow-up after myomectomy with immunohistochemical analysis for $\mathrm{p} 16^{\mathrm{INK} 4 \mathrm{~A}}$, 
p53, Ki-67, estrogen receptors, and progesterone receptors. Int J Gynecol Pathol 28(6): 529-534, 2009. PMID: 198511199. DOI: 10.1097/PGP.0b013e3181a2b8d3

48 Ly A, Mills AM, McKenney JK, Balzer BL, Kempson RL, Gendrickson MR and Longacre TA: Atypical leiomyomas of the uterus: a clinicopathologic study of 51 cases. Am J Surg Pathol 37(5): 643-649, 2013. PMID: 23552831. DOI: 10.1097/PAS. 0b013e3182893f36

49 Yoon BS, Seong SJ and Park H: Rapid recurrence of uterine smooth muscle tumor of uncertain malignant potential as leiomyosarcoma. Int J Gynaecol Obstet 113(3): 244-245, 2011. PMID: 21457977. DOI: 10.1016/j.ijgo.2010.12.021
50 Rizzo A, Pantaleo MA, Saponara M and Nannini M: Current status of the adjuvant therapy in uterine sarcoma: A literature review. World J Clin Cases 7(14): 1753-1763, 2019. PMID: 31417921. DOI: $10.12998 / w j c c . v 7.114 .1753$

Received February 1, 2020 Revised February 11, 2020 Accepted February 13, 2020 